\title{
WHY ARE MIGRATING MALE SHORTFINNED EELS (ANGUILLA AUSTRALIS) IN LAKE ELLESMERE, NEW ZEALAND, GETTING SMALLER BUT NOT YOUNGER ?
}

\author{
D.J. JELLYMAN (1) and P.R. TODD (2)
}

(1) National Institute of Water and Atmospheric Research Ltd, P.O. Box 8602, Christchurch, New Zealand.

(2) Ministry of Fisheries, Private Bag 14, Nelson, New Zealand.

\begin{abstract}
Lake Ellesmere is a large coastal lake in the South Island of New Zealand which supports important commercial fisheries for both feeding and migratory shortfinned eels Anguilla australis. Over the past 50 years, the sex distribution of migratory eels in the lake has changed from a dominance by females to a dominance by males. Age and size data of males have been collected intermittently since 1974. During this time, the mean age has remained relatively constant while the average length has declined by almost $20 \%$. Despite this reduction, length distributions are less variable than weight, condition, or growth rate distributions, and length is considered to be the primary factor associated with the onset of migration. The reduction in average size does not appear to be a result of selective harvest of larger individuals, but must reflect changing environmental conditions in the lake itself - such conditions could include loss of macrophytes, and a reduction in the proportion of larger eels of both species with resultant proliferation of the small benthic bully Gobiomorphus cotidianus. The suggested management strategy is to maximise harvest of migratory male eels and thus reduce the capture of females which are large enough to prey on bullies.
\end{abstract}

Key-words : Anguilla australis, shortfinned eels, length, age, condition, migration.

\section{POURQUOI LES MÂLES MIGRANTS DES ANGUILLES À COURTES NAGEOIRES (ANGUILLA AUSTRALIS) DU LAC ELLESMERE, NOUVELLE-ZÉLANDE, SONT-ILS DE PLUS EN PLUS PLUS PETITS MAIS PAS PLUS JEUNES ?}

\section{RÉSUMÉ}

Le lac Ellesmere est un grand lac côtier de l'lle Sud de Nouvelle-Zélande, qui est le siège d'une pêcherie commerciale importante pour les anguilles à courtes nageoires (Anguilla australis) à la fois au stade d'alimentation et au stade migratoire. Pendant les 50 dernières années, la répartition des sexes des anguilles migratrices du lac a changé, passant d'une majorité de femelles à une majorité de mâles. Des données sur l'âge et la taille ont été relevées de façon intermittente depuis 1974. Pendant cette période, l'âge moyen est resté relativement constant tandis que la longueur moyenne a baissé de presque $20 \%$. Malgré cette réduction, la répartition des longueurs est moins variable que les répartitions des poids, des conditions, ou des taux de croissance, et la longueur est considérée comme le facteur principal associé au déclenchement de la migration. La réduction dans la taille moyenne ne semble pas résulter d'un prélèvement sélectif des individus les plus grands, mais doit refléter des changements dans les conditions 
environnementales du lac lui-même (ces conditions pouvant inclure la disparition des macrophytes) et une réduction dans la proportion des anguilles les plus grandes des deux espèces avec en conséquence une prolifération de la petite espèce benthique Gobiomorphus cotidianus. La stratégie de gestion suggérée est de favoriser au maximum le prélèvement de mâles migrateurs et de réduire ainsi la capture des femelles qui sont suffisamment grandes pour être des prédateurs de Gobiomorphus.

Mots-clés : Anguilla australis, anguilles à courtes nageoires, longueur, âge, condition, migration.

\section{INTRODUCTION}

Lake Ellesmere (Fig. 1) is a large (20 250 ha) coastal lake on the east coast of the South Island, New Zealand, which supports an extensive commercial eel fishery for shortfinned eels Anguilla australis. Historically, the annual seaward migration of migratory eels formed an important fishery to Maori (GOODALL, 1996), and since the early 1970s has been a significant component of the commercial eel fishery, with an average of about $90 \mathrm{t}$ of shortfinned eels taken annually (TODD, 1981a). The lake is separated from the sea by a gravel bar which is opened mechanically at pre-determined levels; as the lake is usually closed during most of the migration season, fishers have access to the migrating eels that congregate at the southwestern corner of the lake, adjacent to the narrowest part of the bar.

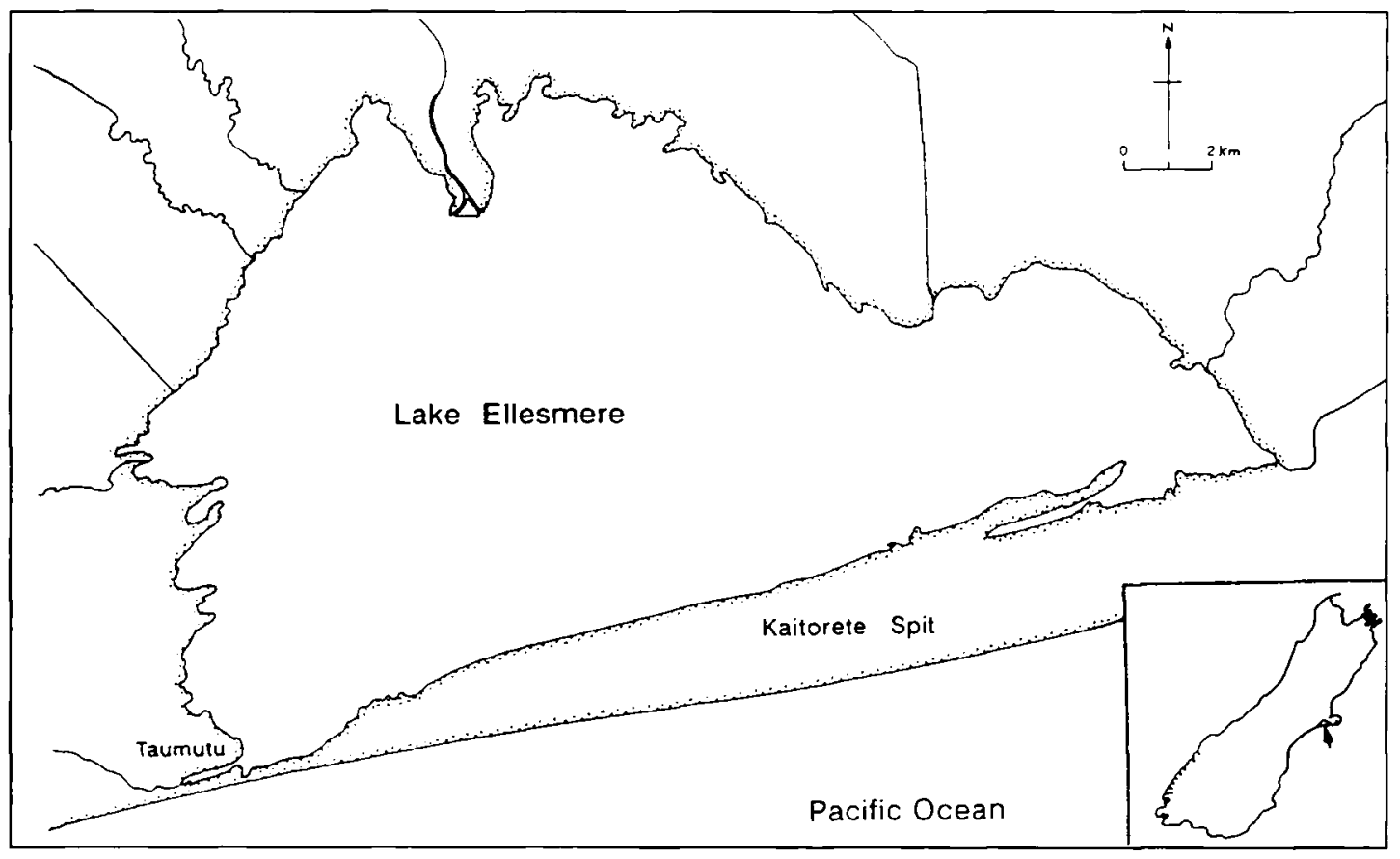

\section{Figure 1}

Map of Lake Ellesmere.

\section{Figure 1}

Carte du lac Ellesmere. 
Although the lake once contained large numbers of longfinned eels, Anguilla dieffenbachii, these have largely disappeared, possibly because they are older at migration than shortfinned eels (JELLYMAN and TODD, 1982) and are hence accessible to commercial fishers over a longer period; they also appear more vulnerable to fyke netting than shortfinned eels (NIWA, unpublished data). The extensive loss of macrophyte beds in the late 1960s has also been suggested as a reason for their decline (JELLYMAN et al., 1995). Shortfinned females were also formerly abundant (HOBBS, 1947), but their numbers have also become greatly diminished, and the migration fishery now concentrates on shortfinned males which are caught from mid February through March.

Migratory (silver) eels form important fisheries in a number of European countries (TESCH, 1977). As such, they have attracted considerable research on factors associated with the timing of their downstream migration (e.g. FROST, 1950 ; LOWE, 1952 ; VOLLESTAD and JONSSON, 1986 ; VOLLESTAD et al., 1994) - similar studies have been carried out in New Zealand by BURNET (1969) and TODD (1981a). Studies of factors associated with the onset of migration in A. anguilla (e.g. FROST, 1950 ; VOLLESTAD and JONSSON, 1986 ; VOLLESTAD, 1992) have concluded that although there is considerable geographic variability, migration is more likely to be associated with achievement of particular size rather than a particular age. The present paper tests the hypothesis that the onset of migration of shortfinned male eels in Lake Ellesmere is more associated with size than age, and explores reasons for the declining size of these eels over time.

\section{METHODS}

Samples of migrating shortfinned male eels were caught in unbaited fyke nets (12 mm mesh), set overnight at Taumutu, Lake Ellesmere. During the 1970's when an extensive research programme was underway, large samples were measured and aged. To complement these and observe any changes over time, further samples were collected during 1992-96. For length-frequency data, eels were anaesthetised in the field, measured (to $1 \mathrm{~mm}$ ) and released. For subsamples retained for ageing, eels were taken to the laboratory where they were measured, weighed (to $0.1 \mathrm{~g}$ ), and otoliths collected. Otoliths were prepared by cracking and burning after the method of HU and TODD (1981). Condition was calculated using $\mathrm{k}=\mathrm{w}^{*} 10^{6} / \mathrm{l}^{3}$ where $\mathrm{w}=$ weight in $\mathrm{g}$, and $\mathrm{I}=$ length in $\mathrm{mm}$. Mean growth rates were calculated from mean length (or weight) /mean age for each year. Data on non-migratory eels came from extensive collections of eels made in the 1970's (NIWA, unpublished data).

\section{RESULTS}

Numbers of eels measured for the various years are given in Table 1. Previous analysis (TODD, 1980) showed that there were no consistent differences in length distributions of males captured at intervals throughout any migratory season. Thus, in the present paper, all samples taken throughout a season were combined into a single sample.

The mean length has reduced from $480 \mathrm{~mm}$ in 1942 (HOBBS, 1947) to $394 \mathrm{~mm}$ in 1996 (Table I, Fig. 2). Further, over time, the shape of the length frequency distributions has remained normal but shifted in favour of smaller eels (Fig. 3) ; similar shifts are evident from weight distributions. The trend for a continued decline in mean length per season has been paralleled by a similar decline in weight until the early 1980's, after which weight has remained relatively constant. Condition was not correlated with length $(p>0.05)$, 


\section{Table I}

Length distributions (\%/year) of migrating male shortfinned eels from Lake Ellesmere, 1972-1996. $<=<0.1$.

\section{Tableau I}

Répartition des longueurs (\%/an) des anguilles (Anguilla australis) mâles migrants du lac Ellesmere, 1972-1996. $<=<0.1$.

\begin{tabular}{|c|c|c|c|c|c|c|c|c|c|c|c|c|c|c|c|}
\hline \multirow{2}{*}{$\begin{array}{c}\text { Size group } \\
(\mathrm{mm})\end{array}$} & \multicolumn{15}{|c|}{ Year } \\
\hline & $197 \hat{2}$ & 1974 & 1975 & 1976 & 1977 & 1978 & 1979 & 1980 & 1981 & 1982 & 1993 & 1994 & 1995 & 1996 & Total \\
\hline $330-339$ & & & & & & & & & & & & & 0.7 & & $<$ \\
\hline $340-349$ & & & & & & & & & & 0.2 & 1.3 & 0.6 & 0.3 & & $<$ \\
\hline $350-359$ & & & & & & 0.1 & $<$ & & 0.2 & 0.2 & 5.1 & 1.3 & 3.7 & 2.8 & 02 \\
\hline $360-369$ & & & 0.1 & $<$ & 0.2 & 0.1 & a & 0.3 & 13 & 17 & 8.9 & 8.1 & 75 & 5.6 & 0.6 \\
\hline $370-379$ & & & 0.3 & 01 & 0.5 & 0.7 & $<$ & 0.8 & 2.6 & 4.3 & 145 & 21.3 & 13.6 & 11.1 & 1.3 \\
\hline $380-389$ & 3.8 & & 0.8 & 12 & 2.4 & 2.3 & 04 & 2.6 & 5.8 & 94 & 17.0 & 18.1 & 23.5 & 17.9 & 29 \\
\hline $390-399$ & 1.9 & 1.6 & 2.7 & 3.0 & 60 & 5.9 & 37 & 6.2 & 11.9 & 173 & 17.4 & 200 & 21.8 & 17.1 & 57 \\
\hline $400-409$ & 5.7 & 3.1 & 6.1 & 7.8 & 171 & 12.4 & 85 & 13.3 & 17.5 & 17.1 & 10.2 & 18.8 & 160 & 171 & 105 \\
\hline $410-419$ & 7.5 & 4.7 & 9.6 & 13.1 & 14.2 & 17.9 & 147 & 18.8 & 19.1 & 173 & 9.8 & 6.3 & 7.5 & 7.9 & 14.6 \\
\hline $420-429$ & 13.2 & 10.4 & 14.2 & 175 & 132 & 18.4 & 18.7 & 19.6 & 16.0 & 12.6 & 9.4 & 2.5 & 4.1 & 7.1 & 16.5 \\
\hline $430-439$ & 132 & 16.1 & 16.6 & 16.9 & 16.1 & 16.4 & 19.2 & 15.3 & 11.8 & 6.6 & 4.7 & 1.3 & 1.0 & 1.6 & 15.9 \\
\hline $440-449$ & 15.1 & 21.3 & 16.3 & 16.5 & 13.9 & 12.7 & 14.1 & 11.7 & 7.8 & 6.0 & 1.7 & 0.6 & 0.3 & 0.4 & 13.1 \\
\hline $450-459$ & 17.0 & 14.6 & 14.2 & 11.8 & 7.5 & 6.6 & 8.6 & 6.3 & 2.8 & 4.3 & & & & 0.8 & 8.5 \\
\hline $460-469$ & 7.5 & 11.5 & 9.2 & 6.6 & 4.6 & 3.3 & 5.5 & 26 & 1.9 & 1.5 & & 0.6 & & & 4.9 \\
\hline $470-479$ & 3.8 & 11.5 & 5.1 & 3.6 & 2.2 & 1.6 & 3.6 & 0.9 & 0.6 & 0.4 & & & & & 2.8 \\
\hline $480-489$ & 5.7 & 3.1 & 3.4 & 1.8 & 1.4 & 0.8 & 1.5 & 0.8 & 0.5 & 0.4 & & 0.6 & & & 1.6 \\
\hline $490-499$ & 1.9 & 0.5 & 1.0 & 0.4 & 0.7 & 0.5 & 07 & 0.4 & 01 & 0.6 & & & & & 05 \\
\hline $500-509$ & 3.8 & 1.0 & 0.2 & 0.3 & & 0.1 & 0.1 & 0.2 & & 0.2 & & & & & 0.2 \\
\hline $510-519$ & & 0.5 & 0.1 & 0.2 & & 02 & 0.3 & 0.1 & & & & & & & 0.2 \\
\hline $520-529$ & & & & & & & 0.2 & 0.2 & & & & & & & 0.1 \\
\hline$N$ & 53 & 192 & 2524 & 2271 & 416 & 2257 & 2091 & 2229 & 857 & 469 & 235 & 160 & 294 & 225 & 14273 \\
\hline Mean & 442.7 & 446.9 & 439.4 & 434.6 & 427.5 & 426.3 & 432.9 & 424.9 & 416.0 & 412.1 & 392.9 & 390.7 & 389.7 & 394.0 & 428.5 \\
\hline $\mathrm{SE}$ & 3.76 & 1.58 & 0.47 & 0.46 & 1.13 & 0.44 & 0.48 & 0.45 & 0.75 & 1.18 & 1.49 & 1.54 & 1.05 & 1.26 & 0.21 \\
\hline $\mathrm{CV}$ & 006 & 0.05 & 0.05 & 0.05 & 0.05 & 0.05 & 005 & 0.05 & 0.05 & 0.06 & 0.06 & 0.05 & 0.05 & 0.05 & 0.06 \\
\hline
\end{tabular}

and the mean condition of all yearly samples showed similar trends to weight, except that condition improved markedly over recent years (Fig. 2). Age distributions (Table II) show a reasonably constant mean age over the 20 years for which data are available, although differences between years were significant (ANOVA, $F=30.22, p<0.001$ ). Much of this difference will be due to variable age-class strengths - for example, age class 15 in 1978 also dominated the 1979 sample (as age class 16) and probably accounted for the greatest average age, 15.6, being recorded in that year; removal of the 1979 data from the age sample reduced the variability in age between years, but differences were still significant $(F=11.56, p<0.001)$. Of all aged males $(n=2206), 67 \%$ were $13-16$ years old.

Variability in size and age over this period (expressed as coefficient of variation, CV, Table III) indicates that weight is the most variable parameter, followed by age and condition, with length being the least variable. The difference is even more marked when comparisons are made between individual years, as variation in length ranged from 0.05 . 0.06 (Table I), whereas variation in age ranged from $0.13-0.18$ (Table II). To see whether migratory eels had a higher average condition than equivalent-sized non-migratory eels, data from 1978 were used; in this year, a large sample of migratory males was measured $(n=2257)$ and a large sample of non-migratory eels of the same length range, 355 $497 \mathrm{~mm}$, was available $(\mathrm{n}=4360)$. The resulting comparison showed that the condition of migratory eels was significantly greater than that of non-migratory eels (ANOVA, $F=295.95, p<0.001$.

There was a significant relationship $(p<0.001)$ between length and age at migration for all data $(n=2206)$, but it only explained $9 \%$ of the variability. As length distributions varied with time, the largest sample aged, $1979(n=514)$ was examined, with similar 
results i.e. $R^{2}=0.03, p<0.001$. In contrast, there was a strong negative relationship between growth rate (mm/yr) and age at maturity (Fig. $4 ; n=2206, R^{2}=0.85, p<0.001$ ). Differences in growth rates in both length and weight were significant over the 20-year period 1975-95 (length growth rate : ANOVA, $F=24.26, p<0.001$; weight growth rate : ANOVA, $F=65.88, p<0.001$ ) with both rates declining with time.

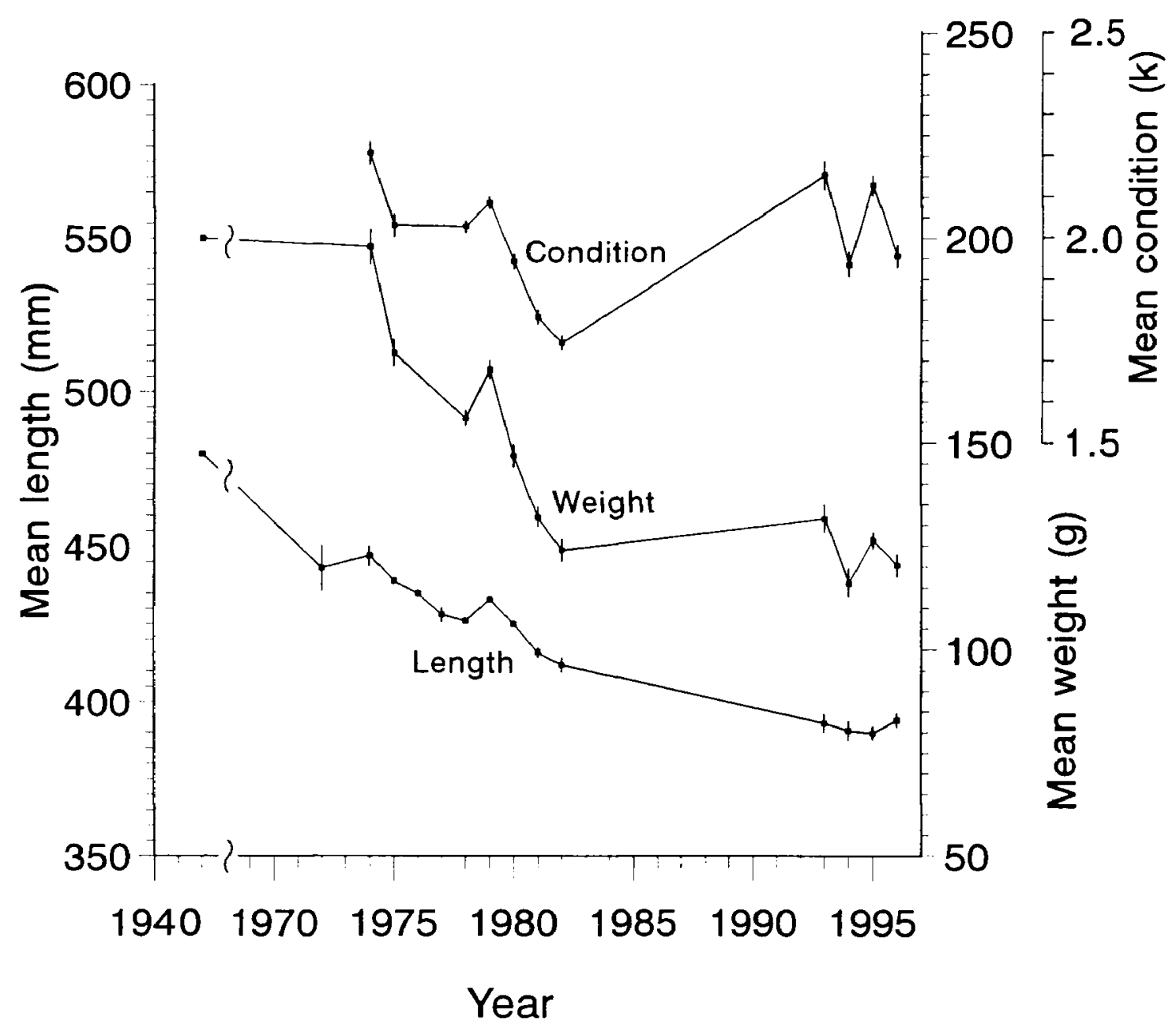

Figure 2

Mean annual length, weight and condition ( \pm 2 SE) of migrating male shortfinned eels from Lake Ellesmere for various years from 1942-1996.

\section{Figure 2}

Moyenne annuelle des longueurs, poids et conditions ( \pm 2 SE) des mâles migrants d'Anguilla australis du lac Ellesmere pour différentes années entre 1942 et 1996. Mean length = longueur moyenne $(\mathrm{mm}) ;$ Mean weight $=$ poids moyen $(\mathrm{g}) ;$ Mean condition $=$ condition moyenne $(k)$; Year $=$ année. 

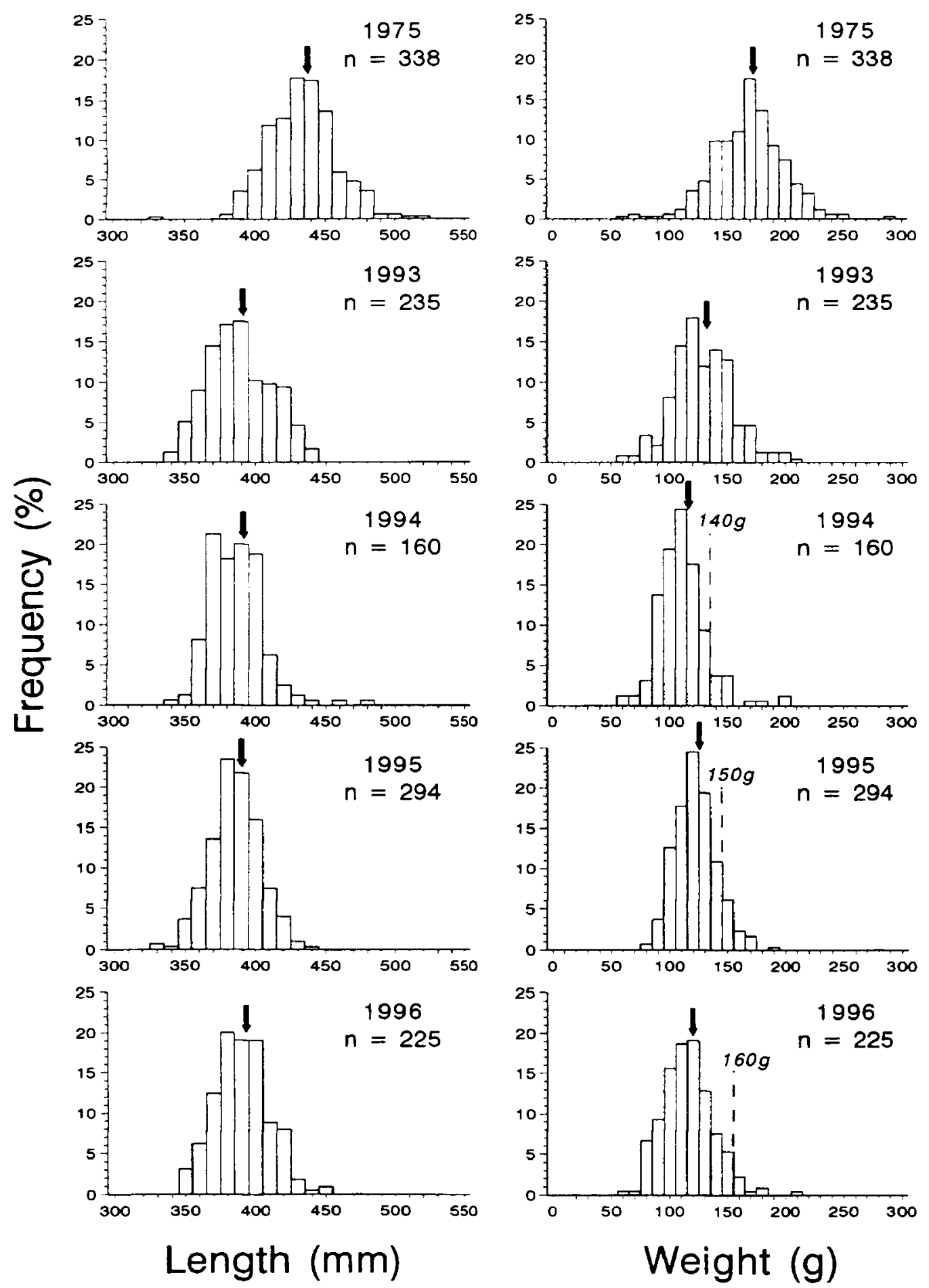

Figure 3

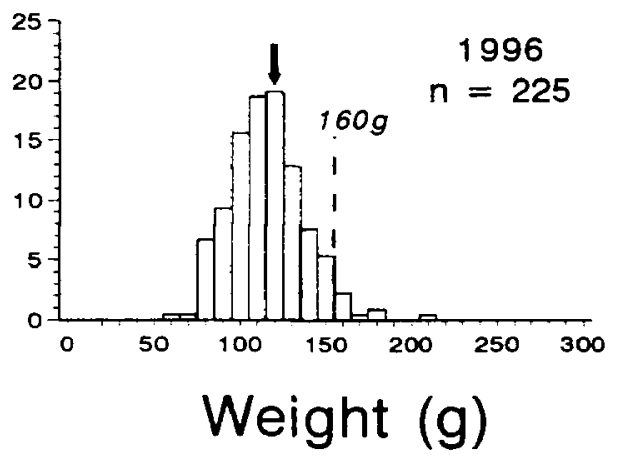

Length and weight frequencies of migrating male shortfinned eels from Lake Ellesmere for 1975 and 1993-96. Arrows show mean values and the dotted line shows the minimum commercial weight for 1994-96.

\section{Figure 3}

Fréquence des longueurs et des poids des mâles migrants d'Anguilla australis du lac Ellesmere pour 1975 et 1993-96. Les flèches indiquent les valeurs moyennes et la ligne pointillée désigne le poids commercial minimum pour 1994-96.

Frequency $=$ fréquence $(\%) ;$ Length $=\operatorname{longueur}(\mathrm{mm}) ;$ Weight $=$ poids $(\mathrm{g})$. 


\section{Table II}

Age distribution (\%/year) of migrating male shortfinned eels from Lake Ellesmere, 1975-1995. $<=<0.1$.

\section{Tableau II}

Répartition des âges (\%/an) des anguilles (Anguilla australis) mâles migrants du lac Ellesmere, 1975-1995. $<=<0.1$.

\begin{tabular}{lccccccccc}
\hline $\begin{array}{c}\text { Age } \\
\text { (years) }\end{array}$ & 1975 & 1978 & 1979 & 1980 & 1981 & 1982 & 1994 & 1995 & $\begin{array}{c}\text { Yotal } \\
(\%)\end{array}$ \\
\hline 8 & & & & & & 0.4 & & & $<$ \\
9 & & 0.3 & 0.2 & 0.3 & & 0.7 & & 1.8 & 0.3 \\
10 & 0.9 & 0.9 & 0.8 & 1.0 & 1.2 & 3.6 & 2.0 & 0.9 & 1.3 \\
11 & 2.3 & 4.0 & 1.2 & 5.2 & 4.3 & 7.3 & 9.8 & 2.7 & 3.9 \\
12 & 8.2 & 8.9 & 4.3 & 8.6 & 6.5 & 18.1 & 9.8 & 9.8 & 8.6 \\
13 & 12.3 & 16.9 & 9.1 & 16.6 & 14.2 & 23.6 & 23.5 & 18.8 & 15.3 \\
14 & 29.2 & 21.5 & 14.0 & 23.6 & 19.4 & 19.9 & 15.7 & 18.8 & 20.1 \\
15 & 21.9 & 24.9 & 17.7 & 16.9 & 16.7 & 10.5 & 11.8 & 19.6 & 18.0 \\
16 & 12.3 & 11.4 & 19.7 & 13.5 & 17.6 & 6.9 & 9.8 & 11.6 & 14.1 \\
17 & 4.6 & 4.9 & 16.2 & 8.3 & 11.4 & 6.9 & 15.7 & 7.1 & 9.7 \\
18 & 3.2 & 3.1 & 9.7 & 3.9 & 6.5 & 1.1 & & 2.7 & 4.9 \\
19 & 2.7 & 2.2 & 4.7 & 1.6 & 1.2 & 0.7 & & 0.9 & 2.3 \\
20 & 0.5 & 0.3 & 2.1 & 0.3 & 0.6 & 0.4 & 2.0 & 2.7 & 1.0 \\
21 & 1.4 & 0.3 & & 0.3 & 0.3 & & & 1.8 & 0.2 \\
22 & & 0.3 & 0.4 & & & & & 0.9 & $<$ \\
23 & 0.5 & & & & & & & & \\
24 & & & & & & & & & \\
& & & & & & & & \\
$\mathrm{~N}$ & 219 & 325 & 514 & 385 & 324 & 276 & 51 & 112 & 2206 \\
Mean & 14.6 & 14.4 & 15.6 & 14.4 & 14.8 & 13.5 & 14.1 & 14.6 & 14.7 \\
SE & 0.13 & 0.11 & 0.09 & 0.10 & 0.11 & 0.12 & 0.30 & 0.24 & 0.05 \\
CV & 0.14 & 0.13 & 0.13 & 0.13 & 0.14 & 0.14 & 0.15 & 0.18 & 0.14 \\
\hline
\end{tabular}

\section{Table III}

Variation in length $(\mathrm{mm})$, weight $(\mathrm{g})$, condition, age and growth rate $(\mathrm{mm} / \mathrm{yr}, \mathrm{g} / \mathrm{yr})$ of migrating male shortfinned eels from Lake Ellesmere, 1974-1996.

\section{Tableau III}

Variation de la longueur ( $\mathrm{mm}$ ), du poids (g), de la condition, de l'âge et du taux de croissance (mm/an, g/an) des anguilles (Anguilla australis) mâles migrants du lac Ellesmere, 1974-1996.

\begin{tabular}{lcccccc}
\hline & & & & & Growth & $\begin{array}{c}\text { Growth } \\
\text { rate } \\
\text { rate } \\
\text { (weight) }\end{array}$ \\
\hline $\mathrm{N}$ & Length & Weight & Condition & Age & 2206 \\
Mean & 14273 & 3678 & 3678 & 2206 & 2206 & 2206 \\
Minimum & 428.5 & 146.3 & 1.99 & 14.65 & 29.30 & 10.32 \\
Maximum & 330.0 & 60.0 & 1.00 & 8.0 & 14.46 & 4.06 \\
SD & 529.0 & 366.0 & 4.05 & 28.0 & 47.44 & 24.71 \\
SE & 24.8 & 34.0 & 0.24 & 2.11 & 4.11 & 2.22 \\
CV & 0.21 & 0.56 & 0.01 & 0.05 & 0.09 & 0.05 \\
\hline
\end{tabular}




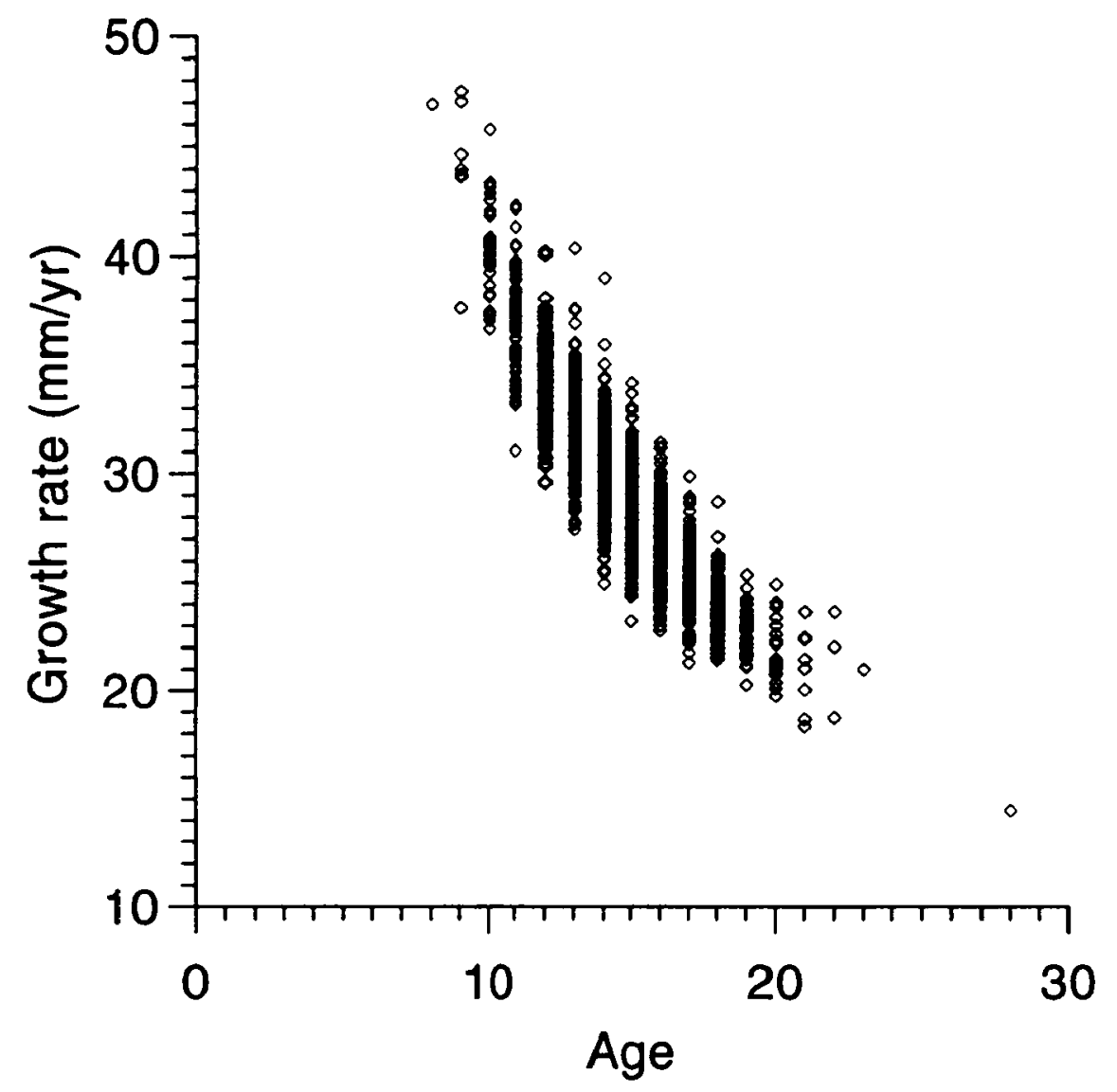

Figure 4

Relationship between mean annual growth rate $(\mathrm{mm} / \mathrm{yr})$ and age of migrating male shortfinned eels from Lake Ellesmere.

\section{Figure 4}

Relation entre le taux de croissance annuel moyen ( $\mathrm{mm} / a n n e ́ e)$ et l'âge des mâles migrants d'Anguilla australis du lac Ellesmere.

Growth rate $(\mathrm{mm} / \mathrm{yr})=$ taux de croissance $(\mathrm{mm} / \mathrm{année})$

\section{DISCUSSION}

\section{Which factors are associated with the onset of migration ?}

Over the 23 years of record, there has been little change in the mean age of shortfinned males although there is a range of 13-14 years in most years (Table II). Over the same period, average length and weight have both declined substantially (12 and 39\%, respectively) and at first glance this might be interpreted as meaning that age rather than size determines the onset of migration. However, the coefficient of variation (CV) for length is still less than that for age, indicating that length rather than age is a more likely determinant of migration.

Variation in growth rate explained $85 \%$ of the variation in length at migration, with slow growth associated with greater age but more rapid growth associated with lesser age. Similar relationships have been found for both sexes of $A$. anguilla (VOLLESTAD, 1992) ; SVEDANG et al. (1996) interpreted the same trend in female $A$. anguilla as indicating a 
strategy of maturing at the earliest possible opportunity. This is in agreement with theory that males exhibit a time-minimising strategy (HELFMAN et al., 1987 ; LARSSON et al., 1990 ; VOLLESTAD, 1992), with emphasis on attaining maturity as quickly as possible. Unlike females where greater size is accompanied by increased fecundity (e.g. TODD, 1981b), there would seem to be little benefit for males to grow large, as observations of artificial spawning do not indicate mate selection (SORENSEN and WINN, 1984) where larger size might otherwise be advantageous.

Research on other species of Anguilla has sometimes indicated that migration is more associated with size than age (e.g. TESCH, 1977 ; VOLLESTAD and JONSSON, 1986). In contrast, TODD (1980) suspected that for male $A$. australis, migration might be more dependent on age than length, although the considerable range in both factors meant he could not draw any firm conclusions. From the present study, it is concluded that length is a better predictor of the onset of maturity than is age. Although the minimum length recorded has continued to decline over time, minimum weight has been reasonably stable over the last 4 years of record indicating a possible minimum threshold size of about $65 \mathrm{~g}$, which equates to $335 \mathrm{~mm}$.

As migrating males from the present study had a significantly greater condition than non-migratory eels of similar size, it is likely that attainment of a threshold condition is a further prerequisite to maturation. Thus, having attained an appropriate size, male eels also need to be of sufficient condition (through accumulation of sufficient lipid reserves) to undertake a migration of about $5000 \mathrm{~km}$ (JELLYMAN, 1987). In a similar manner to the way in which mesenteric fat levels are important for regulating maturity in Atlantic salmon, Salmo salar (ROWE et al., 1991), the fat content of migratory eels has been suggested as influencing the onset of maturity in A. anguilla (LARSSON et al., 1990).

\section{Why has the average size declined?}

TODD (1980) assumed that the decline in length observed from 1942 to 1980 was due to commercial fishing selectively removing the larger males. If this was so and the larger males were caught when they exceeded the current minimum commercial size, then it should be evident from a changing skew in size frequency distributions, and there would be no reason to suppose a shift to smaller minimum sizes over time. Although there has been no change in the shape of the length-frequencies over time, the minimum size has declined e.g. in 1974, there were no eels of $100 \mathrm{~g}$ or less, but by 1996 this size group comprised $32 \%$ of samples. Further, the time-frame involved would seem to mitigate against commercial fishing being the mechanism involved i.e. intensive commercial fishing commenced in 1971 (287 t ; JELLYMAN et al., 1995), but by the following year (the first year since 1942 that length data were recorded) mean lengths had declined by $33 \mathrm{~mm}$ from those recorded by HOBBS (1947) in 1942. It seems unlikely that commercial fishing could have produced such a rapid decline within one year, and it is concluded that the decline in average size is mainly due to eels achieving maturity at a smaller size.

\section{Why has the growth rate declined?}

Growth rates of New Zealand eels seem largely density dependent (JELLYMAN, 1997). As Lake Ellesmere eels were heavily exploited during the mid 1970's (JELLYMAN et al., 1995), it might have been expected that growth rates would have increased as a result of commercial fishing, in a similar manner to that recorded by CHISNALL and HAYES (1991) in Lake Waahi. In contrast, growth rates of male migrants (this study) and small non-migrant eels (JELLYMAN et al., 1995) have both declined. Suggested explanations for reduced growth rates are long-term environmental changes within the lake, or an increase in the abundance of small eels. 
During the past 30-40 years, a number of significant ecological changes have occurred within the lake, with the most significant being increased eutrophication (HUGHES et al., 1974 ; WARD et al.. 1996), changes in salinity resulting from changed opening regimes in the 1960s (GERBEAUX, 1993), and the loss of macrophytes during the 1960's with associated increased turbidity. Possibly, some of these changes have been detrimental to eels. For example, they could have resulted in changes to food composition, similar to changes that accompanied increased turbidity in Lake Waahi (HAYES and RUTLEDGE, 1991). However, given the plasticity of eels diet (CAIRNS, 1942 ; JELLYMAN, 1989), it seems unlikely that any changes in food composition would have disadvantaged eels.

Increased recruitment seems unlikely as recruitment is largely determined by the timing and duration of the artificial opening of the lake, and this has not changed significantly over the past 20 years. However, a reduction in mortality of juvenile eels is a distinct possibility as a result of the selective removal of larger eels of both species which are known predators of juvenile eels (BURNET, 1952 ; JELLYMAN, 1989). The scale of the reduced abundance of larger eels is apparent from comparing the estimate of HOBBS (1947) of 500 tons $(=508 \mathrm{t})$ of shortfinned females migrating in 1942, with an estimate of only 2-3 t during 1996 (T.J. GOULD, pers. comm.). Similarly, the sex proportions of migratory eels have changed dramatically from a dominance by females $(4.6: 1$; calculated from HOBBS, 1947), to a dominance by males (1996 estimates $=235: 1$ ).

The lake also contains a dense population of common bullies (Gobiomorphus cotidianus) which eel fishers claim has increased over recent years. This reported increase may also be a result of the reduction in the number of larger eels that would formerly have imposed some predatory constraints on bully numbers. As both bullies and juvenile eels frequent inshore areas (JELLYMAN et al., 1995) and eat similar food (e.g. chironomid larvae, mysids, and snails), they might directly compete for food. The net result of increased survival of juvenile eels and limited food would be a reduction in growth rates of juvenile eels.

\section{Management implications}

The Lake Ellesmere eel fishery is managed by a Total Allowable Commercial Catch of $136.5 \mathrm{t}$, and a present minimum size limit of $160 \mathrm{~g}(1995 / 96$ season) which increases at a rate of $10 \mathrm{~g} /$ year to reach $220 \mathrm{~g}$ in the 2002/03 season As virtually all migrating male eels are less than this size ( $96 \%$ in 1996), almost all eels harvested by the commercial fishery are, by definition, females. If the theory is correct that the reduction in the number of large female eels is at least partly responsible for the proliferation of bullies (which in turn reduce the food available to small eels), then the fishery should maximise capture of male eels and minimise capture of females. To enable this, an exclusion zone was gazetted in March 1996, for that part of the lake where male eels congregate in their endeavours to leave the lake. Provided such a measure can be implemented annually, there should be a corresponding increase in the abundance of female eels, and hopefully an increase in both size and growth rates of males.

\section{ACKNOWLEDGEMENTS}

We thank former Ministry of Agriculture and Fisheries staff, LU CHI HU and TIM DODGSHUN, for their painstaking measuring and ageing of the extensive samples collected during the 1970s and 80s, and BEN CHISNALL, NIWA, HAMILTON, for ageing the 1994 and 1995 eels. We also wish to thank MARTY BONNETT for helpful comments on the text. 


\section{REFERENCES}

BURNET A.M., 1952. Studies on the ecology of the New Zealand longfinned eel, Anguilla dieffenbachii Gray. Australian Journal of Marine and Freshwater Research, 3, 3263.

BURNET A.M.R., 1969. Migrating eels in a Canterbury river, New Zealand. New Zealand Journal of Marine and Freshwater Research, 3, 230-243.

CAIRNS D., 1942. Life-history of the two species of freshwater eel in New Zealand. II. Food and inter-relationships with trout. New Zealand Journal of Science, 23, 132148.

CHISNALL B.L., HAYES J.W., 1991. Age and growth of shortfinned eels (Anguilla australis) in the lower Waikato basin, North Island, New Zealand. New Zealand Journal of Marine and Freshwater Research, 25, 71-80.

FROST W.E., 1950. The eel fisheries of the River Bann, Northern Ireland and observations on the age of silver eels. Journal du Conseil International pour l'exploration de la mer, 16, 358-383.

GERBEAUX P., 1993. Potential for re-establishment of aquatic plants in Lake Ellesmere (New Zealand). Journal of Aquatic Plant Management, 31, 122-128.

GOODALL A., 1996. Te Waihora - te kete ika. In TAYLOR K.J.W. (ed.), The natural resources of Lake Ellesmere (Te Waihora) and its catchment, 145-153, Canterbury Regional Council, Christchurch, New Zealand.

HAYES J.W., RUTLEDGE M.J., 1991. Relationship between turbidity and fish diets in Lakes Waahi and Whangape. New Zealand Journal of Marine and Freshwater Research, 25, 297-304.

HELFMAN G.S., FACEY D.J., HALES J.L.S., BOZEMAN J.E.L., 1987. Reproductive ecology of the American eel. American Fisheries Society Symposium, 1, 42-56.

HOBBS D.F., 1947. Migrating eels in Lake Ellesmere. Transactions and Proceedings of the Royal Society of New Zealand, 77, 228-232.

HU L.C., TODD P.R., 1981. An improved technique for preparing eel otoliths for aging. New Zealand Journal of Marine and Freshwater Research, 15, 445-446.

HUGHES H.R., MCCOLL R.H.S., RAWLENCE D.J., 1974. Lake Ellesmere. A review of the lake and its catchment. Information series 99, New Zealand Department of Scientific and Industrial Research, $27 \mathrm{p}$.

JELLYMAN D.J., 1987. Review of the marine life history of Australasian temperate species of Anguilla. American Fisheries Society Symposium, 1, 276-285.

JELLYMAN D.J., 1989. Diet of two species of freshwater eel (Anguilla spp.) in L'ake Pounui, New Zealand. New Zealand Journal of Marine and Freshwater Research, 23, 1-10.

JELLYMAN D.J., 1997. Variability in growth rates of freshwater eels (Anguilla spp.) in New Zealand. Ecology of Freshwater Fish, 6, 108-115.

JELLYMAN D.J., TODD P.R., 1982. New Zealand freshwater eels : their biology and fishery. New Zealand Ministry of Agriculture and Fisheries, Fisheries Research Division Information Leaflet, 11, $19 \mathrm{p}$.

JELLYMAN D.J., CHISNALL B.L., TODD P.R., 1995. The status of the eel stocks of Lake Ellesmere. NIWA Science and Technology Series, 26, $62 p$.

LARSSON P., HAMRIN S., OKLA L., 1990. Fat content as a factor inducing migratory behavior in the eel (Anguilla anguilla L.) to the Sargasso Sea. Naturwissenschaften, $77,488-490$.

LOWE R.H., 1952. The influence of light and other factors on the seaward migration of the silver eel (Anguilla anguilla L.). Journal of Animal Ecology, 21, 275-309. 
ROWE D.K., THORPE J.E., SHANKS A.M., 1991. Role of fat stores in the maturation of male Atlantic salmon (Salmo salar) parr. Journal of Fish Biology, 47, 652-670.

SORENSEN P.W., WINN H.E., 1984. The induction of maturation and ovulation in American eels, Anguilla rostrata (Le Sueur), and the relevance of chemical and visual cues to male spawning behaviour. Journal of Fish Biology, 25, 261-268.


European eel: age and size at the silver eel stage. Journal of Fish Biology. 48, 342-351.

TESCH F.W., 1977. The eel. Biology and management of anguillid eels. Chapman and Hall, London, $434 \mathrm{p}$.

TODD P.R., 1980. Size and age of migrating New Zealand freshwater eels (Anguilla spp.). New Zealand Journal of Marine and Freshwater Research, 14, 283-293.

TODD P.R., 1981a. Timing and periodicity of migrating New Zealand freshwater eels (Anguilla spp.). New Zealand Journal of Marine and Freshwater Research, 15, 225235.

TODD P.R., 1981b. Morphometric changes, gonad histology, and fecundity estimates in migrating New Zealand freshwater eels (Anguilla spp.). New Zealand Journal of Marine and Freshwater Research, 15, 155-170.

VOLLESTAD L.A., 1992. Geographic variation in age and length at metamorphosis of maturing European eel : environmental effects and phenotypic plasticity. Journal of Animal Ecology, 61, 41-48.

VOLLESTAD L.A., JONSSON B., 1986. Life-history characteristics of the European eel Anguilla anguilla in the Imsa River, Norway. Transactions of the American Fisheries Society, 115, 864-871.

VOLLESTAD L.A., JONSSON B., HVIDSTEN N.A., NESTJE T.F., 1994. Experimental test of environmental factors influencing the seaward migration of European silver eels. Journal of Fish Biology, 45, 641-651.

WARD J.C., FIETJE L., FREEMAN M.C., HAWES I., SMITH V.R., TAYLOR K.J.W., 1996. Water quality of the lake and tributaries. In TAYLOR K.J.W. (ed.), The natural resources of Lake Ellesmere (Te Waihora) and its catchment, 105-143, Canterbury Regional Council, Christchurch, New Zealand. 